\title{
Impact of different tillage methods on growth, development and productivity of maize (Zea mays)-wheat (Tritcum aestivum) cropping system
}

\author{
Ramesh $^{1 *}$, S. S. Rana $^{2}$, Suresh Kumar ${ }^{3}$ and R. S. Rana ${ }^{1}$ \\ ${ }^{1}$ Centre for Geo-informatics Research and Training, Chaudhary Sarwan Kumar Himachal Pradesh Krishi Vish- \\ vavidyalaya, Palampur - 176062 (Himachal Pradesh), INDIA \\ ${ }^{2}$ Department of Agronomy, Forages and Grassland Management, Chaudhary Sarwan Kumar Himachal Pradesh \\ Krishi Vishvavidyalaya, Palampur - 176062 (Himachal Pradesh), INDIA \\ ${ }^{3}$ Directorate of Extension Education, Chaudhary Sarwan Kumar Himachal Pradesh Krishi Vishvavidyalaya, Palam- \\ pur - 176062 (Himachal Pradesh), INDIA \\ ${ }^{*}$ Corresponding author. E-mail: rameshhpkv@gmail.com \\ Received: February 4, 2016; Revised received: July 1, 2016; Accepted: October 22, 2016
}

\begin{abstract}
An experiment was conducted on a silty clay loam soil of Palampur during 2009-2011, to study the effect of different tillage methods in maize (Zea mays L.) wheat \{Triticum aestivum (L.) emend. Fiori \& Paol.\} cropping system. Results revealed that in maize crop, tillage methods in kharif season resulted in significantly highest emergence count $\left(27.1\right.$ plant $\left./ \mathrm{m}^{2}\right)$ under manual seed drill. While, multi-crop planter recorded in significantly taller plants $(55.4 \mathrm{~cm})$ at 30 DAS; higher dry matter accumulation $81.0,990.0$ and $4184.4 \mathrm{~g} / \mathrm{m}^{2}$ at 30,60 and 90 DAS, respectively and CGR $\left(30.3 \mathrm{~g} / \mathrm{day} / \mathrm{m}^{2}\right)$ at 30-60 DAS. Tillage methods in rabi season resulted in higher emergence count (17.6 plant $/ \mathrm{m}^{2}$ ) under zero tillage. This treatment also recorded advanced emergence by 1.2 to 1.5 days. In wheat crop, tillage methods in kharif season resulted in significantly highest emergence count $\left(307.6\right.$ plant $\left./ \mathrm{m}^{2}\right)$, taller plants $(13.1$ $\mathrm{cm})$ at 30 DAS, dry matter accumulation $\left(625.3 \mathrm{~g} / \mathrm{m}^{2}\right)$ at 120 DAS and CGR $\left(14.4 \mathrm{~g} / \mathrm{day}^{2} \mathrm{~m}^{2}\right)$ at $90-120$ DAS under conventional tillage. While, tillage methods in rabi season resulted in significantly highest emergence count (369.5 plants $\left./ \mathrm{m}^{2}\right)$, tallest plants $(17.7,92.6$ and $101.0 \mathrm{~cm}$ at 60,120 and at harvest, respectively) with multi-crop planter. While, zero tillage recorded significantly higher CGR $\left(15.8 \mathrm{~g} /\right.$ day $\left./ \mathrm{m}^{2}\right)$ and RGR $(0.027 \mathrm{~g} / \mathrm{g} /$ day $)$ during 120 -harvest stage. Zero tillage produced statistically at par crop yield and rainwater-use efficiency of both crops with other tillage treatments. Hence, zero tillage can be as good as other intensive tillage system besides lower input cost and environmental security.
\end{abstract}

Keywords: CGR, Maize-wheat, Rainwater use efficiency, RGR, Zero tillage

\section{INTRODUCTION}

Himachal Pradesh is the only state in the country whose 89.96 percent population lives in rural area having agriculture as main occupation (Anonymous, 2015). And about 14 percent of the total State Gross Domestic Product comes from agriculture and its allied sectors. Maize-wheat cropping system is the most dominant cropping system in the State and is followed under rainfed conditions as about $80 \%$ of cultivated area lacks irrigation facilities resulting in lower productivity. Further, uneven distributions of rains on undulating land holding do not encourage hill farmers to adopt new farming practices as their counterparts. Under rainfed condition, using suitable tillage practices according to climate and soil characteristics is very important, because of its effect on soil properties which varies from region to region (Mujdeci et al., 2010). Modified management practices including intensive tillage operations are being advocated for improving resource-use efficiency and crop productivity.
However, research results showed that intensive tillage practices declined soil structure and stability over years due to depletion of soil organic matter, resulting in soil susceptible to erosion (Schneider et al., 2012). The conventional (intensive) tillage systems thus may not be suited to hilly areas already prone to excessive soil erosion hazards. Therefore, minimum and zero tillage are recommended for Indian Himalayan region due to reduced cultivation cost, higher retention of soil water and increased soil organic carbon (Bhattacharyya et al., 2012).

Adoption of resource conserving technologies like zero tillage has emerged as a means of achieving the sustainability of intensive cropping systems (Sharma et al., 2012). In zero tillage, the crops are sown with minimum disturbance of soil by placing the seeds in a narrow slit about 3-4 $\mathrm{cm}$ wide and 4-7 $\mathrm{cm}$ deep without land preparation. Inspite of reducing cultivation cost, zero tillage also improve the soil fertility through increased soil carbon accumulation and biological activity (Bhan and Behera, 2014) and mitigate the green 
house gas emission (Timsina and Connor, 2001). Hence, to increase and sustain the productivity of agricultural systems it is important to identify appropriate soil management practices concomitant with friendly environment and efficient utilization of production resources. Thus, the present experiment was designed to evaluate the effect of different tillage/planting techniques on growth, development and yield of maizewheat cropping system.

\section{MATERIALS AND METHODS}

An experiment was conducted for maize-wheat cropping system at Palampur during kharif 2009 to rabi 2011. The geographical co-ordinates of experimental field were $32^{\circ} 6^{\prime} \mathrm{N}$ latitude and $76^{\circ} 3^{\prime} \mathrm{E}$ longitude and an altitude of 1,290 meters above mean sea level. The soil of the experimental site was silty clay loam in texture with $\mathrm{pH} 5.06$, had $1.1 \%$ organic carbon, $323.0 \mathrm{~kg}$ / ha alkaline permanganate oxidized N, $25.8 \mathrm{~kg} /$ ha available $\mathrm{P}$ and $276.4 \mathrm{~kg} / \mathrm{ha} 1 \mathrm{~N}$ ammonium acetate exchangeable $\mathrm{K}$ at the time of initiation of study. During kharif season maize crop experienced well distributed rainfall of 1,342.1 and 2,148.0 mm during 2009 and 2010, respectively. During rabi season wheat crop received 361.9 and $557.2 \mathrm{~mm}$ rainfall during 2009-10 and 2010-11, respectively. Maize-wheat system was raised in sequence with 16 treatment combinations in strip-plot design with 3 replications. Treatments in horizontal plots were (Maize, kharif): $\mathrm{M}_{1}$-sowing by power tiller-operated zero till drill; $\mathrm{M}_{2}$-sowing by power tiller-operated multi-crop planter; $\mathrm{M}_{3}$-sowing by

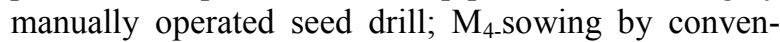
tional method (sowing behind the hand plough); and in vertical plots (wheat, $r a b i$ ): $\mathrm{W}_{1}$-sowing by power tilleroperated zero till drill; $\mathrm{W}_{2}$-sowing by power tiller operated multi-crop planter; $\mathrm{W}_{3}$-sowing by manually operated seed drill; $\mathrm{W}_{4}$-sowing by conventional method (sowing behind the hand plough). Maize 'Girija Composite' and wheat 'HPW 155' were sown during both the years under irrigated conditions. The recommended dose of $\mathrm{N}, \mathrm{P}_{2} \mathrm{O}_{5}$ and $\mathrm{K}_{2} \mathrm{O}$ for maize and wheat was 120:60:40 and 120:60:30 kg/ha, respectively. Entire $\mathrm{P}$ and $\mathrm{K}$ were applied at the time of sowing to both the crops. In maize, $\mathrm{N}$ was applied in 3 equal splits (at sowing, knee-high and tasseling stage) whereas in wheat, half $\mathrm{N}$ at the time of sowing and remaining $\mathrm{N}$ was applied in 2 splits at tillering and earing stage. To control the weeds, Atrazine at $1.25 \mathrm{~kg} /$ ha followed by (fb.) $2,4-\mathrm{D}$ at $1.00 \mathrm{~kg} / \mathrm{ha}$ in maize crop and Isoproturon at $1.20 \mathrm{~kg} / \mathrm{ha} \mathrm{fb} .2,4-\mathrm{D}$ at $1.00 \mathrm{~kg} / \mathrm{ha}$ in wheat crop were applied during both years. However, at later growth period of crops, weeds were also removed manually. All observations for each character were subjected to statistical analysis according to the standard method (Gomez and Gomez 1984) and were tested at 5 per cent level of significance to interpret the treatment differences. Pooling was done over the seasons and mean data are given. Crop growth rate (CGR) and relative growth rate (RGR) of both crops was calculated by the formulae outlined by Watson (1962). Rainwater-use efficiency (RWUE) of both crops was computed as per Mupangwa et al. (2016).

\section{RESULTS AND DISCUSSION}

\section{Maize crop}

Growth studies: Tillage/planting techniques in kharif (Table 1) showed that emergence count was highest $\left(27.1 \mathrm{plant} / \mathrm{m}^{2}\right)$ in manual seed drill followed by multicrop planter. The count in these two treatments was about 3 and 2 times higher than the required normal population. This showed that the machines have used higher seed rate and for their proper calibration still more work has to be done. However, the low emergence count in zero tillage might be due to more compact soil and less soil-seed contact. Tillage methods in rabi also showed that emergence count was above the optimum under all the treatments. But it was significantly higher under zero till seeded plots $\left(17.6\right.$ plants $\left./ \mathrm{m}^{2}\right)$ over conventional and multi-crop planter planted crop.

Tillage methods in kharif further showed that sowing with multi-crop planter remaining at par with manual seed drill resulted in significantly taller plants (55.4 $\mathrm{cm})$ at $30 \mathrm{DAS}$; and higher dry matter accumulation $81.0,990.0$ and $4184.4 \mathrm{~g} / \mathrm{m}^{2}$ at 30,60 and 90 DAS, respectively and CGR (30.3 g/day/ $\left./ \mathrm{m}^{2}\right)$ during 30-60 DAS as compared to zero tillage. While, conventional tillage remaining at par with zero tillage recorded significantly higher RGR (0.098 g/g/day) over multi-crop planter and manual seed drill. This increase in growth parameters under multi-crop planter could be ascribed to better pulverization of soil which might have helped in better air exchange, soil moisture and nutrient availability resulting in higher values of all growth parameters over zero tillage. The lower growth of maize in zero tillage may be ascribed to greater soil bulk density and soil penetration resistance which adversely affects the root growth resulting less nutrients removal from soil and high crop-weed competition. Chopra and

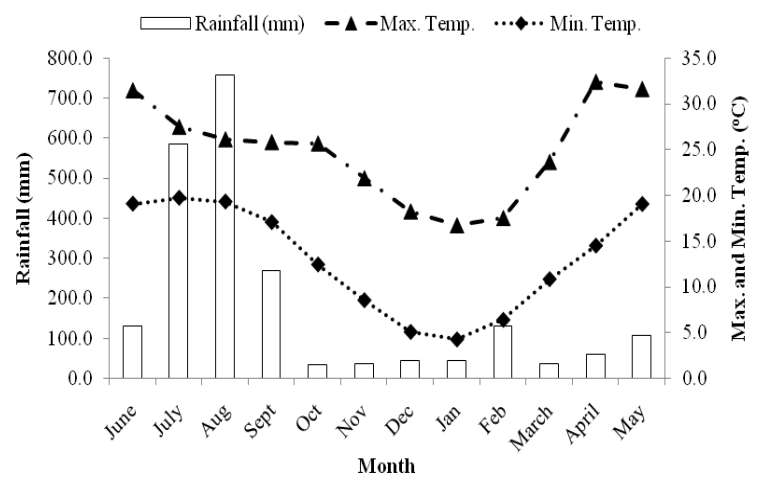

Fig. 1. Mean monthly weather data of the experimental site (mean of 2009-2011). 
Ramesh et al. / J. Appl. \& Nat. Sci. 8 (4): 1861-1867 (2016)
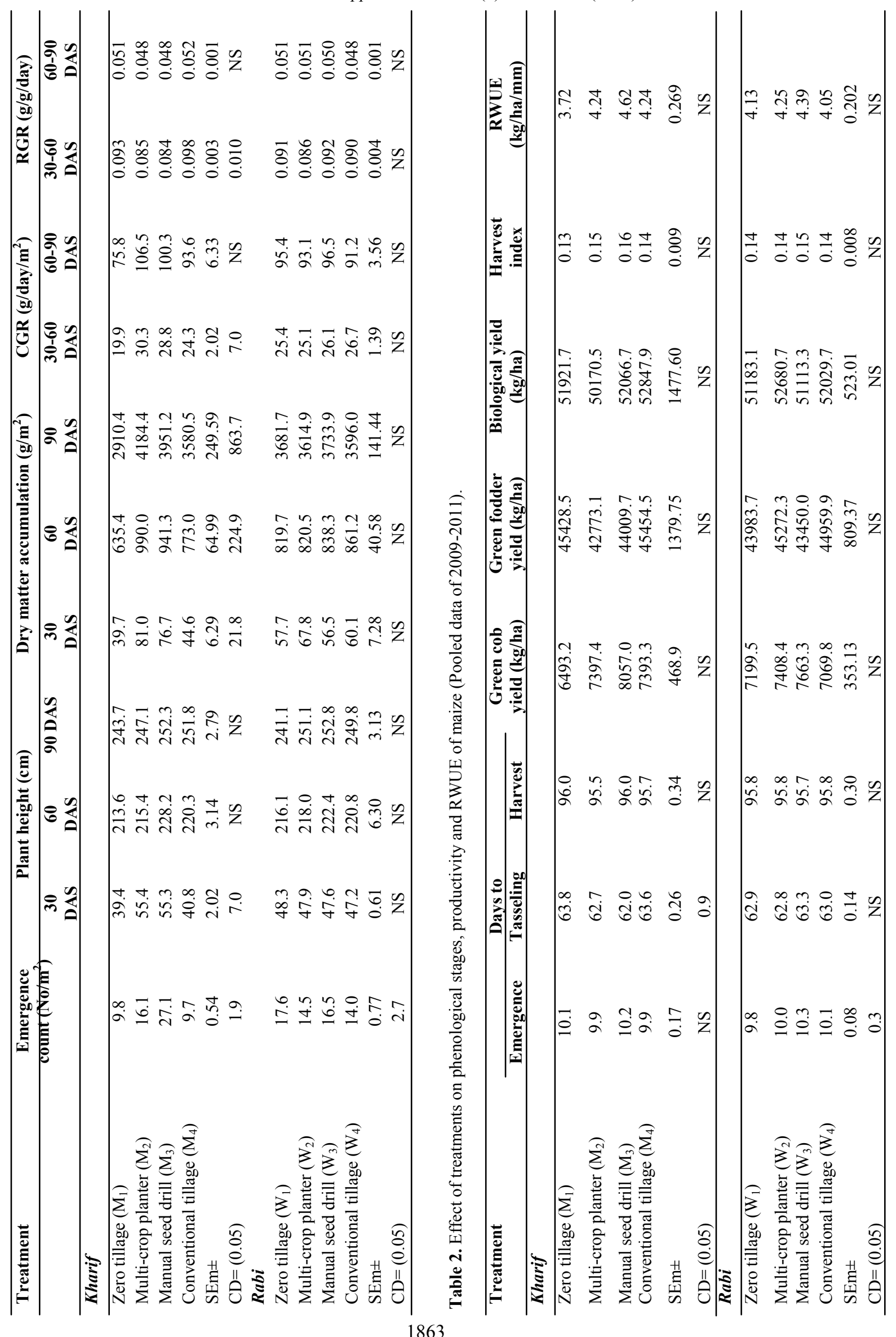


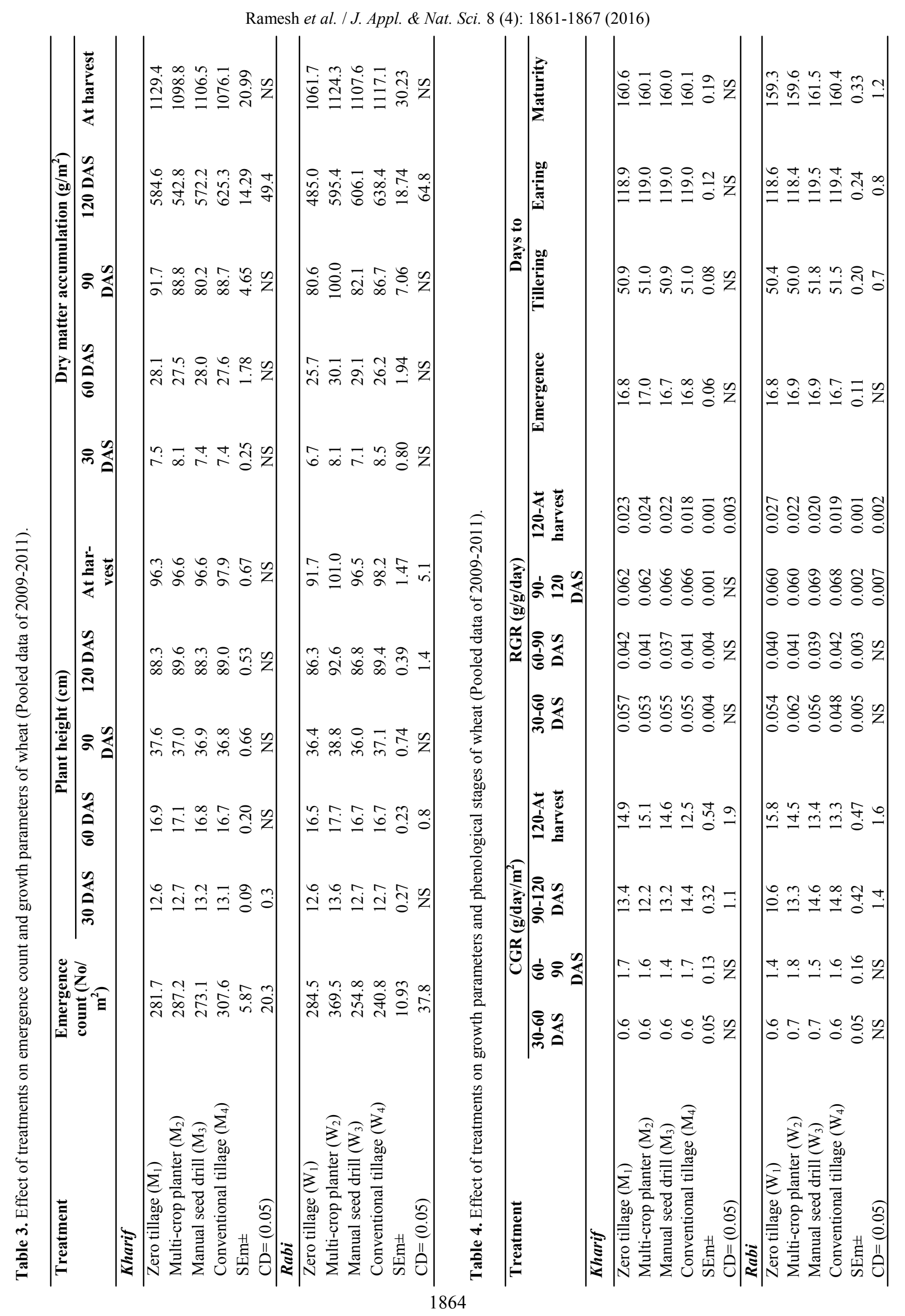




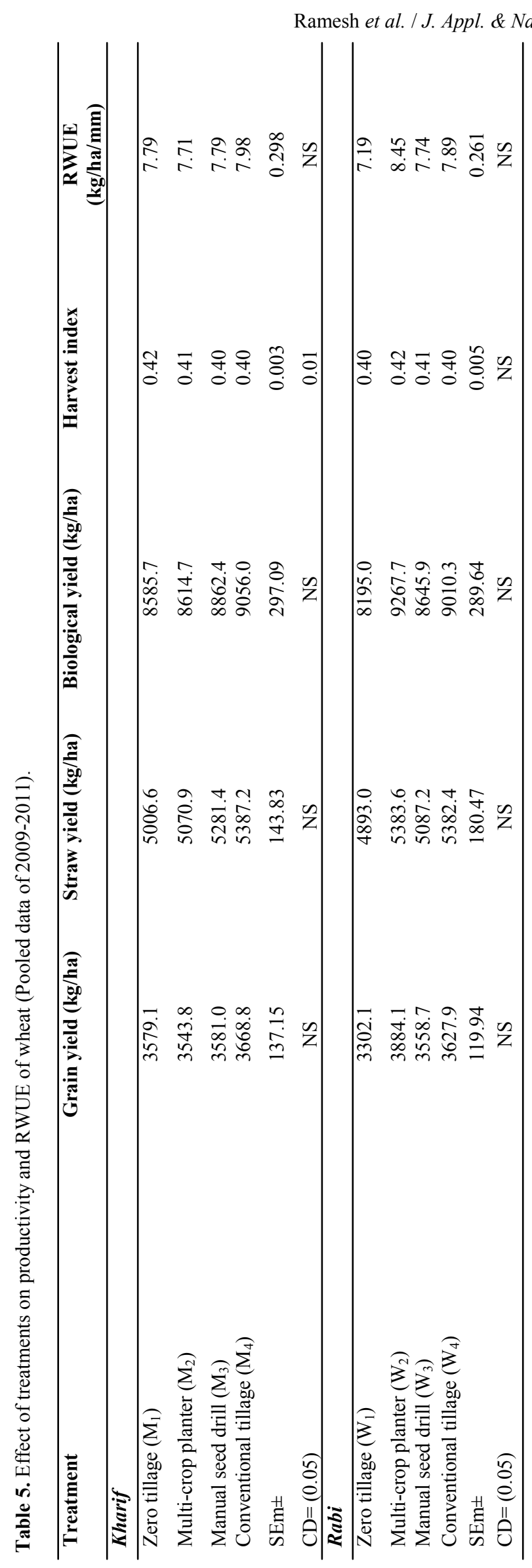

Angiras (2008) and Yusuf (2006) also reported similar results under zero tillage as compared to tillage systems. Tillage methods in rabi did not shows any significant results on growth parameters of maize.

Development studies: Zero tillage being statistically at par with conventional tillage took significantly more days to tasseling as compared to manual seed drill and multi-crop planter sown maize in kharif season (Table 2 ). Both of the later i.e. manual seed drilled and multicrop planter were at par with each other. This could be ascribed to the prolonged vegetative phase of the crop under high crop-weed competition and unfavourable soil conditions in zero and conventional tillage. Tillage methods in rabi showed significant effect on days to emergence where, manual seed drill remaining at par with conventional tillage took significantly more number of days to emergence which was at par with conventional tillage. Zero tillage in rabi had advanced emergence of maize by 0.2 to 0.5 days than the other tillage management techniques. This might be due proper placement of seed for quick emergence under the zero till drill planting. Days to tasseling and harvesting were not significantly influenced by tillage methods in rabi season.

Yield: Green cob, green fodder, biological yield and harvest index was not significantly influenced by tillage methods in kharif as well as rabi season (Table 2). However, the green cob yield was comparatively more under manual seed drill, but the differences were not significant. The lower population under zero tillage did not significantly influenced cob yield of maize. But maize green cob yield under the zero till sowing was low enough over the other treatments. The results further revealed that all tillage systems produced statistically similar grain yield which is quite encouraging regarding zero tillage because of lower inputs cost. Less soil disturbance under zero tilled soil might have increased the microbial population and organic biomass which further might have increased the yield which compensated by compensating the slower growth of crop at the end. The results are in accordance with Ram et al. (2010), who reported that maize yield did not differ significantly among zero tillage and conventional tillage.

RWUE: Tillage methods in kharif as well as rabi season did not significantly influenced the RWUE of maize. However, manual seed drill recorded higher values in both season as compared to other treatments. Higher value in this tillage method might be due to higher water retention which resulted in higher economic yield hence higher RWUE.

\section{Wheat crop}

Growth studies: Tillage/planting techniques in kharif and rabi season significantly influenced the emergence count of wheat. During kharif seasons, conventional tillage resulted in significantly highest emergence count (307.6 plant $/ \mathrm{m}^{2}$ ) over all other tillage methods 
which were significantly at par with each others. Tillage methods in rabi showed that emergence count was significantly highest under multi-crop planter (369.5 plant $/ \mathrm{m}^{2}$ ) as compared to others.

In case of plant height and dry matter accumulation, tillage methods in kharif showed that manual seed drill remaining at par with conventional tillage had taller plants $(13.2 \mathrm{~cm})$ at 30 DAS. However, slower growth under zero tillage and multi-crop planter was compensated at later stages. Conventional tillage also recorded highest dry matter accumulation $\left(625.3 \mathrm{~g} / \mathrm{m}^{2}\right)$ at 120 DAS as compared to other tillage methods. At harvest, zero tillage was as good as others which was owed to less intra-row competition and increased resource use efficiency as compared to others. Tillage methods in rabi showed a different trend where multi-crop planter recorded tallest plants $17.7,92.6$ and $101.0 \mathrm{~cm}$ at 60 , 120 and at harvest, respectively as compared to other treatments. While, conventional tillage remaining at par with manual seed drill and multi-crop planter resulted in higher dry matter accumulation $\left(638.4 \mathrm{~g} / \mathrm{m}^{2}\right)$ at $120 \mathrm{DAS}$. Zero tillage recorded lowest dry matter accumulation at all growth stages indicating visible ill effects which are expected to be further pronounced over the years. This was observed by build-up of certain perennial weeds species such as Cynodon dactylon after the harvest of wheat crop. Also, the roots of wheat crop in no till drill plants were shallower and were not able to extract the nutrients and moisture available at deeper layers. However, higher dry matters in conventional seeding might be due to better soil conditions like lower bulk density, better nutrient and moisture availability from deeper layer. Higher dry matter accumulation in conventional seeding due to good soil conditions due to better pulverization of soil than the other tillage treatments was in accordance with Khan et al. (2014). Tillage/planting techniques in kharif season significantly influenced the CGR (90120 DAS and 120-harvest) and RGR (120-harvest) (Table 4). Conventional tillage $\left(14.4 \mathrm{~g} / \mathrm{day} / \mathrm{m}^{2}\right)$ remaining at par with zero tillage $\left(13.4 \mathrm{~g} / \mathrm{day} / \mathrm{m}^{2}\right) \mathrm{rec}-$ orded significantly higher CGR during 90-120 DAS while same treatment recorded lowest CGR (12.5 g/ day $/ \mathrm{m}^{2}$ ) during 120 -harvest stage. RGR during 120 harvest stage was higher in multi-crop planter $(0.024$ $\mathrm{g} / \mathrm{g} /$ day) which was at par with zero tillage and manual seed drill. Tillage/planting techniques in rabi season showed that CGR and RGR during 90-120 DAS were higher in conventional tillage $\left(14.8 \mathrm{~g} / \mathrm{day} / \mathrm{m}^{2}\right.$ and 0.068 $\mathrm{g} / \mathrm{g} /$ day, respectively) which was at par with manual seed drill. However, during 120-harvest stage zero tillage recorded higher CGR $\left(15.8 \mathrm{~g} / \mathrm{day} / \mathrm{m}^{2}\right)$ and RGR $(0.027 \mathrm{~g} / \mathrm{g} /$ day $)$ as compared to other tillage methods.

Development studies: Tillage/planting techniques in kharif season did not significantly influence the phenophases of wheat (Table 4). While tillage in rabi season showed that multi-crop planter and zero till seed- ing remaining at par with each other took lesser number of days (1.5 to 1.8 days) to tillering, earing and maturity than manual seed drill and conventionally seeded crop.

Yield: Like maize yield, wheat grain yield was not significantly different either owing to tillage treatments in kharif as well as rabi season (Table 5). However, the grain yield was comparatively more under conventional tillage and multi-crop planter, but the differences were not significant. The comparable (similar) effect of tillage/planting treatments suggested that there is no need to go for intensive tillage operations and zero tillage can be a good practice under the present condition atleast for the initial years. The farmers of the state can follow any method of their choice depending upon the resources available Similar grain yield under zero and conventional tillage was also noted by Monsefi et al.(2016) showing that wheat can be grown very successfully under zero tillage condition as the productivity was nearly similar compared with conventional tillage. However, zero tillage in kharif season recorded significantly higher harvest index which was at par with multi-crop planter as compared to conventional tillage and manual seed drill planting. This might be due to higher economic and straw yield ratio under zero tillage.

RWUE: Likewise in maize crop, tillage methods in kharif as well as rabi season did not significantly influenced the RWUE of wheat. However, conventional tillage in kharif and multi-crop planter in rabi season recorded higher values of RWUE as compared to other owing to higher yield in these treatments.

\section{Conclusion}

The present study concluded that sowing of maize $(Z$. mays) with manual seed drill and wheat ( $T$. aestivum) under multi-crop planter was more beneficial for improving productivity and profitability of $Z$. mays. Further, both the crops can be grown very successfully under zero tillage as the productivity was nearly similar compared with conventional tillage. Similarly, grain yield is quite encouraging regarding zero tillage because of lower input cost and environmental security. This further suggested that there is no need to go for intensive tillage operations and zero tillage can be as good as other practices under the present condition at least for the initial years.

\section{REFERENCES}

Anonymous. (2015). Economic survey of Himachal Pradesh 2014-15. Economics and Statistics Department, Govt. of Himachal Pradesh. 157 pp.

Bhan, S. and Behera, U.K. (2014). Conservation agriculture in India - Problems, prospects and policy issues. International Soil and Water Conservation Research, 2(4): 1-12

Bhattacharyya, R., Tuti, M.D., Kundu, S., Bisht, J.K. and Bhatt, J.C. (2012). Conservation tillage impacts on soil aggregation and carbon pools in a sandy clay loam soil 
of the Indian Himalayas. Soil Science Society of America Journal, 76: 617-627

Chopra, P. and Angiras, N.N. (2008). Effect of tillage and weed management on productivity and nutrient uptake of maize (Zea mays). Indian Journal of Agronomy, 53 (1): 66-69

Gomez, K.A. and Gomez, A.A. (1984). Statistical procedure for agricultural research, (Edn 2) Wiley Inter Science, New York, USA. 680 pp.

Khan, A., Jan, M., Jan, A., Shah, Z.A. and Arif, M.T. (2014). Efficiency of dry matter and nitrogen accumulation and redistribution in wheat as affected by tillage and nitrogen management. Journal of Plant Nutrition, 37(5): 723-737

Monsefi, A., Sharma, A.R. and Rang Zan, N. (2016). Weed management and conservation tillage for improving productivity, nutrient uptake and profitability of wheat in soybean (Glycine max)-wheat (Triticum aestivum) cropping system. International Journal of Plant Production, 10(1): 1-12

Mujdeci, M., Kara, B. and IsiIdar, A.A. (2010). The effects of different soil tillage methods on soil water dynamic. Scientific Research and Essays, 5(21): 3345-3350

Mupangwa, W., Twomlow, S. and Walker, S. (2016). Reduced tillage and nitrogen effects on soil water dynamics and maize (Zea mays L.) yield under semi- arid conditions. International Journal of Agricultural Sustainability, 14(1): 13-30

Ram, H., Kler, D.S., Singh, Y. and Kumar, K. (2010). Productivity of maize (Zea mays)-wheat (Triticum aestivum) system under different tillage and crop establishment practices. Indian Journal of Agronomy, 55(3): 185-90

Schneider, F., Steiger, D., Ledermann, T., Fry, P. and Rist, S. (2012). No-tillage farming: Co-creation of innovation through network building. Land Degradation and Development, 23: 242-255

Sharma, A.R., Jat, M.L., Saharawat, Y.S., Singh, V.P. and Singh, R. (2012). Conservation agriculture for improving productivity and resource-use efficiency: Prospects and research needs in Indian context. Indian Journal of Agronomy, 57(IAC Special Issue): 131-140

Timsina, J. and Connor, D.J. (2001). Productivity and management of rice-wheat cropping systems: Issues and challenges. Field Crops Research, 69(2): 93-132

Watson, D.J. (1962). The physiological basis of variations in yield. Advances in Agronomy, 4: 101-145

Yusuf, D.D. (2006). Effect of variation in tillage systems on maize (Zea mays L.) establishment and grain yield in semi-arid tropical climate. Journal of Agricultural Science and Technology, 8: 171-179 